\title{
PENGRARUH PENGEMBALIAN MODAL TERHADAP HARGA SAHAM \\ PADA PT MULTI BINTANG INDONESIA TAHUN 2011-2020
}

\author{
Supatmin \\ Staf Pengajar Fakultas Ekonomi Universitas Pamulang \\ Email: dosen01767@unpam.ac.id
}

\begin{abstract}
ABSTARK.
Tujuan dari penelitian adalah untuk mengetahui seberapa besar pengaruh "Pengembalian Modal" terhadap Harga Saham. Olah data "Quantitatif" merupakan metode yang dipergunakan dalam riserch ini, dengan Sampel penelitian sebanyak 10 tahun. Uji prasyarat serta uji-uji yang lainnya dengan mempergunakan yaitu uji $t$ dengan menggunakan alat bantu SPSS Versi 24. Hasil penelitian menunjukkan bahwa adanya hubungan antara Variable "X" terhadap Variable "Y"..
\end{abstract}

Kata Kunci: Pengembalian modal serta Harga Saham

\section{ABSTRACT}

The study aims to identify the Reurn On Assets, Earning Per Share. "The research used is quatitattive method". The sample in the research were 10 years. The study using analysis test the Asumsion Classical and regression analysis linier the hipothesis for statistical tests that is test $t$ with uset the tools spss version 24."The Reserch results show this a variable "ReturnOnAssets" to "EarningPerShare".

\section{Keywords: "return on assetsa and earning per share".}

\section{PENDAHULUAN}

A. Latar Belakang.

Dalam perekonomian Indonesia mulai akan terlihat dari sumbangsih pergerakan dan aktifitas dari kegiatan industri, terlihat dari tahun ke tahun sumbangsih sektor ini di Indonesia sangat menonjol guna perkembangan pembangunan nasional.

Dewasa ini pemegang peranan yang sangat penting dan sebagai kunci dalam pembangunan adalah sektor industri, hal ini terjadi karena sektor industri mempunyai beberapa keunggulan jika dibandingkan dengan sektor-sektor yang lainnya, diantaranya membutuhkan tenaga kerja dalam volume yang sangat besar.

Pertumbuhan perusahaan mulai mengalami peningkatan, sehingga dibagunlah di Kabupaten Tangerang brewery cabang yang kedua. Selanjutnya perusahaan berganti nama pada tahun yang sama yaitu menjadi PT Bir Indonesia. PT yang baru berganti nama ini mulai beroperasi pada tanggal 1 Januari 1973 yang telah lalu. Proses selanjutnya pada tanggal 1 bulan Januari tahun 1981, PT Brasseries de I'Indonesia diambil alih dalam pengelolaannya dengan minuman ringan di medan dan Bir sebagai hasil produksinya. 
JRNAL ПMПAH

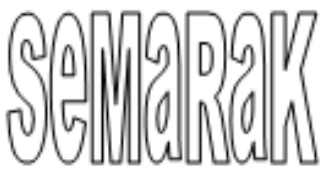

P-ISSN 2615-6849, E-ISSN 2622-3686

Jurnal Semarak,Vol.4,No.2,Juni 2021, Hal (90-97)

@Prodi Manajemen Fakultas Ekonomi Universitas Pamulang
Dalam aktifitas akuisisi dan peningkatan usaha mulai 2 September 1981, memindahkan tempat dan kedudukan perusahaan ke Jakarta Saham dari perusahaan ini juga tercatat di Bursa Efek Indonesia.

Berdasarkan "Natar Adri 2011:83" bahwa "Earning Per Share (EPS) adalah pengukuran ats laba bersih setelah pajak (net income after tax) pada satutahun buku terhadap jumlah saham yang diterbitkan (outstanding share)."

Berdasarka pendapat Pirmatua Sirait tahun 2017:142, Return on Assets berpengertian: "Rasio Imbal Hasil Aset (return on assets/ROA) disebut juga rasio kekuatan laba (earning power ratio), menggambarkan kemampuan perusahaan dalam menghasilkan laba dari sumber daya (aset) yang tersedia".

Dalam tahun terakhir Return On Assets PT Multi Bintang Indonesia Tbk mengalami penurunan. Selanjutnya maka penulis dapat menunjukan rangkuman perkembangannya antara lain tertera di bawah ini (Tabel 1.1):

Tabel 1.1

Perkembangan data Return On Assets (ROA)

PT. Multi Bintang Indonesia Tbk, Periode 2011-2020 (dalam jutaan)

\begin{tabular}{|c|c|c|c|c|c|}
\hline Tahun & Laba Bersih (RP) & Total aset (RP) & Hasil (\%) & \multicolumn{2}{|c|}{ Ket $\%$} \\
\hline 2011 & 442,916 & $1,137,082$ & 38.95 & & \\
\hline 2012 & 507,382 & $1,220,813$ & 41.56 & Naik & $2 . \epsilon$ \\
\hline 2013 & 453,405 & $1,152,048$ & 39.36 & Turun & 2.2 \\
\hline 2014 & $1,171,229$ & $1,782,148$ & 65.72 & Naik & 26.3 \\
\hline 2015 & 794,883 & $2,231,051$ & 35.63 & Turun & $30 . C$ \\
\hline 2016 & 496,909 & $2,100,853$ & 23.65 & Turun & $11 . c$ \\
\hline 2017 & 982,129 & $2,275,038$ & 43.17 & Naik & 19.5 \\
\hline 2018 & $1,322,067$ & $2,510,078$ & 52.67 & Naik & 9.5 \\
\hline 2019 & $1,224,807$ & $2,889,501$ & 42.39 & Turun & 10.2 \\
\hline 2020 & $1,206,059$ & $2,896,950$ & 41.63 & Turun & 0.7 \\
\hline
\end{tabular}

Dari tabel 1.1. diatas menunjukan bahwa perkembangan ROA ditahun 2013, 2015 dan 2016 serta pada tahun 2019 dan 2020 mengalami penurunan sebesar 2,20\% untuk tahun 2013, 30,09\% serta 11,98\% untuk tahun 2015 dan 2016. Adapun penurunan di tahun berikutnya yaitu pada tahun 2019 sebesar $10,28 \%$ serta penurunan di tahun 2020 sebesar $0,760 \%$. Dengan pengertian bahwa Return On Assetss (ROA) sangat mempengaruhi suatu Perseroan Terbatas karena sering mengalami kenaikan dan penurunan angka dalam setiap tahunnya secara fluktuatif. Data kenaikan bisa dilihat pada tabel 1.1 perkembangan Return On Assets di atas.

Adapun Rasio EPS PT Multi Bintang Indonesia Tbk setiap tahunnya juga mengalami fluktuatif dari tahun ketahunnya, maka penulis juga akan tampilkan perkembangannya serta pergerakan Rasio EPS antara lain terlihat di bawah ini:

Tabel 1.2

Perkembangan data Earning PerShare (EPS)

PT Multi Bintang Indonesia Tbk Periode 2011-2020 (dalam jutaan)

\begin{tabular}{|c|c|c|c|c|c|}
\hline Tahun & \begin{tabular}{|c|} 
Laba Bersih Setelah \\
Pajak (Rp)
\end{tabular} & \begin{tabular}{|c|} 
Jumlah Saham Beredar \\
(Rp)
\end{tabular} & Hasil (\%) & \multicolumn{2}{|c|}{ Ket $\%$} \\
\hline 2011 & 442,916 & $21,070,000$ & 2.10 & & \\
\hline 2012 & 507,382 & $21,070,000$ & 2.41 & Naik & 0.31 \\
\hline 2013 & 453,405 & $21,070,000$ & 2.15 & Turun & 0.26 \\
\hline 2014 & $1,171,229$ & $21,070,000$ & 5.56 & Naik & 3.41 \\
\hline 2015 & 794,883 & $21,070,000$ & 3.77 & Turun & 1.79 \\
\hline 2016 & 496,909 & $21,070,000$ & 2.36 & Turun & 1.41 \\
\hline 2017 & 982,129 & $21,070,000$ & 4.66 & Naik & 2.30 \\
\hline 2018 & $1,322,067$ & $21,070,000$ & 6.27 & Naik & 1.61 \\
\hline 2019 & $1,224,807$ & $21,070,000$ & 5.81 & Turun & 0.46 \\
\hline 2020 & $1,206,059$ & $21,070,000$ & 5.72 & Turun & 0.09 \\
\hline
\end{tabular}

Sumber: Data di olah 2021

Dari tabel 1.2. diatas menunjukan bahwa perkembangan Earning Per Share tahun 2013, 2015, 2016 dan 2019 serta tahun 2020 mengalami penurunan sebesar $0,26 \%$ untuk tahun 2013, 1,79\% tahun 2015 serta $1,41 \%$ untuk tahun 2016. Sedangkan tahun 2019 mengalami penurunan sebesar $0,46 \%$ serta 0,09\% untuk tahun 2020. Dengan demikian kondisi ini menunjukkan bahwa Earning Per Share juga sangat mempengaruhi suatu perusahaan karena sering mengalami kenaikan dan penurunan angka dalam setiap tahunnya secara fluktuatif. Data kenaikan tersebut terlihat padatabel yang disajikan yaitu Tabel Perkembangan Earning Per Share (EPS) di Tabel 1.3.

Dengan memperhatikan dan menyimak data yang disajikan di atas maka penulis tertarik untuk menganalisa dan mengetahui lebih dalam perihal "Pengaruh Return On Assets terhadap Earning Per Share pada PT Multi Bintang Indonesia Tbk periode 2011-2020"

B. Rumusan Masalah 
JRNAL ПMПAH

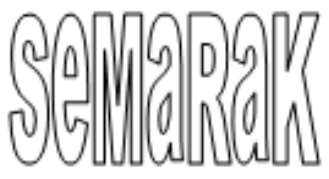

Sesuai dengan latar belakang masalah dan data di atas, selanjutnya penulis dapat memfokuskan untuk perumusan masalah pada penelitian ini antara lain 1). "Berapa Besar hubungan Pengembalian Modal (ROA) dan Harga Saham (EPS) di PT "Multi Bintang Indonesia Tahun 2011-2020?

\section{Tujuan Penelitian}

Tujuan dalam Riserch ini adalah: 1) Mendapatkan hasil besarnya Pengembalian modal (ROA) jika dihubungkan dengan Harga saham (EPS) di PT Multi Bintang Indonesia Tbk.

\section{TINJAUAN PUSTAKA}

Selanjutnya pengelolaan keuangan yang baik akan mencerminkan perusahaan tersebut berhasil atau tidaknya dalam mengelola keuangannya. Manajer keuangan dalam perusahaan tugasnya sangatlah berat yaitu tercapainya tujuan perusahaan. Manajer keuangan dibebani tugas lebih banyak dalam pencapaian tujuan perusahaan yaitu manager keuangan agar mendapatkan cara guna mengupayakan dan memakai dana yang telah disediakan sehingga perusahaan dapat berjalan dengan mulus dan baik sesuai terge yang telah disepakati bersama dan jika memungkinkan akan melebihi target yang sudah ditetapkan.

Banyak arti dan makna dari "Management Keuangan" yang diungkapkan oleh para ilmuwan diantaranya akan disampaikan dibawah ini antara laian:

1) Berdasarkan pendapat Brigham dan Joel: 2010:6 "Seni atau Art dan ilmu atau Science untuk mengatur uang, yang terdiri dari proses, institusi atau lembaga, dan pasar, serta instrumen yang akan terlibatdengan masalah pertransferan uang antara individu dan bisnis serta pemerintah" disebut Manajemen Keuangan.

2) Berdasarkan Pendapat James C. Van Home 2013:5 "Semua kegiatan perusahaan yang ada kaitannya dan akan terkait atau terhubung untuk mendapatkan, kegitan pembiayaan serta pemakaian modal yang diikuti dengan mencapai tujuan perusahaan secara keseluruhan disebut juga dengan Manajemen Keuangan. Ini pengertian manajemen keuangan dari ilmuwan tersebut.

Dengan demikian dapat ditarik kesimpulan "Bahwa kegiatan yang berhubungan dengan merencanakan, mengumpulkan atau dan mencari untuk pendanaan, dan memanfaatkan modal serta memakai dan menggunakan modal perusahaan guna bisa menjalakan kegitankegiatan operasi perusahaan guna untuk mengejar tujuan perusahaan yang sudah ditetapkan bersama oleh perusahaan disebut "Management Keuangan".

\section{A. Tujuan Management Keuangan \\ Berdasarkan Martono dan agus 2011:13 "Memaksimalkan dan} memakmurkan Perusahaan atau pemegang saham dengan alat ukur dari harga saham perusahaan tersbut" itu yang disebut dengan tujuan Management perusahaan.

Ilmuwan yang lain mengatakan"brigham serta houston" 2010:132 berpendapat dalam "yulianto" mengyampaikan "Dengan memaksimalkan kekayaan pemegang saham dalam jangka yang panjang, akan tetapi hal ini bukan untuk memaksimalkan ukuran akuntansi seperti laba bersih atau Earning Per Share" disebut juga dengan makda dan tujuan "Management Keuangan”.

Selanjutnya kesimpulannya adalah "Memaksimalkan nilai perusahaan serta memaksimumkan kemakmuran pemegang saham" ini disebut Tujuan Management Keuangan.

\section{B. Management Keuangan.}

"Manajemen keuangan atau sering disebut pembelanjaan dapat diartikan sebagai semua aktivitas perusahaan yang berhubungan dengan usaha-usaha mendapatkan dana perusahaan dengan biaya yang murah serta usaha untuk menggunakan dan mengalokasikan dana tersebut secara efisien". 
JRNAL ПMПAH

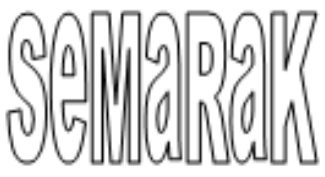

P-ISSN 2615-6849, E-ISSN 2622-3686

Jurnal Semarak,Vol.4,No.2,Juni 2021, Hal (90-97)

@Prodi Manajemen Fakultas Ekonomi Universitas Pamulang
Financial management "merupakan segala kegiatan ataupun aktivitas pada perusahaan yang berhubungan dengan bagaimanakah caranya agar bisa mendapatkan pendanaan modal kerja, menggunakan atau mengalokasikan dana tersebut serta mengelola asset yang telah dimiliki perusahaan guna mencapai tujuan utama pada suatu perusahaan".

Berdasarkan pendapat "horne serta Wochowicz jr": 2012:2. "manajemen Keuangan mengemukakan bahwa manajemen keuangan berkaitan dengan perolehan aset, pendanaan, dan manajemen aset dengan didasari beberapa tujuan umum".

Sedangkan berdasarkan "sudana" 2011: "Management Finance sebagai bagian Finance mengelola aturan Finance di lokasi atau otoritas perusahaan yang bermanfaat untuk menciptakan guna memperkuat dan menahan nilai perusahaan dengan cara mdapat mengambil keputusan serta mengolah personil atau SDM yang lebih baik dan lebih tepat guna.

\section{Financial Statements.}

Financial Statements dikatakan lengkap biasanya meliputi neraca, laporan laba rugi, kondisi finansial dalam organisasi perusahaan terdiri dari Balance Sheets akan tercermin atau terlihat posisi keuangan antara laian "Aktiva, Utang serta Modal Sendiri" yang terlihat pada suatu saat yang tertentu. Sedangkan Incame Statement akan terlihat kondisi penghasilan yang sudah dicapai pada periode tertentu, yang lazim biasanya tersajikan dalam laporan tahunan atau tercermin dalam satu tahun berjalan.

\section{Return On Assets}

Berdasarkan pendapat "Mamduh serta Halim" 2012:157: "ROA adalah mengukur kemampuan perusahaan menghasilkan laba pada masa lalu. Kemudian diproyeksikan ke masa depan untuk melihat kemampuan perusahaan menghasilkan laba pada masa-masa mendatang. ROA mengukur kemampuan perusahaan menghasilkan laba menggunakan total aset yang diounyai perusahaansetelah disesuaikan dengan biaya-biaya untuk mendanai aset tersebut" Sedangkan Menurut Lestari dan Sugiharto (2007:196), Return On Asset (ROA) adalah rasio yang digunakan untuk mengukur keuntungan bersih yang diperoleh dari penggunaan aktiva. Dengan kata lain, semakin tinggi rasio ini maka semakin baik produktivitas asset dalam memperoleh keuntungan bersih. Pengembalian Modal ini bisa diukur antara lain : Pengembalian Modal = Keuntungan Bersih dibagi Jumlah Modal dikalikan 100\% (Sumber Lestari 2007).

Dalam kesempatan ini akan disampaikan rumus "EPS" berdasarlkan pendapat Kasmir antara lain: "EPS = Keuntungan bersih dibagi banyaknya "Total Shares Outstanding” dikali 100\%

\section{E. Kerangka Berfikir.}

Selanjutnya kesempatan sekarang akan mempergunakan kerangka antara lain:

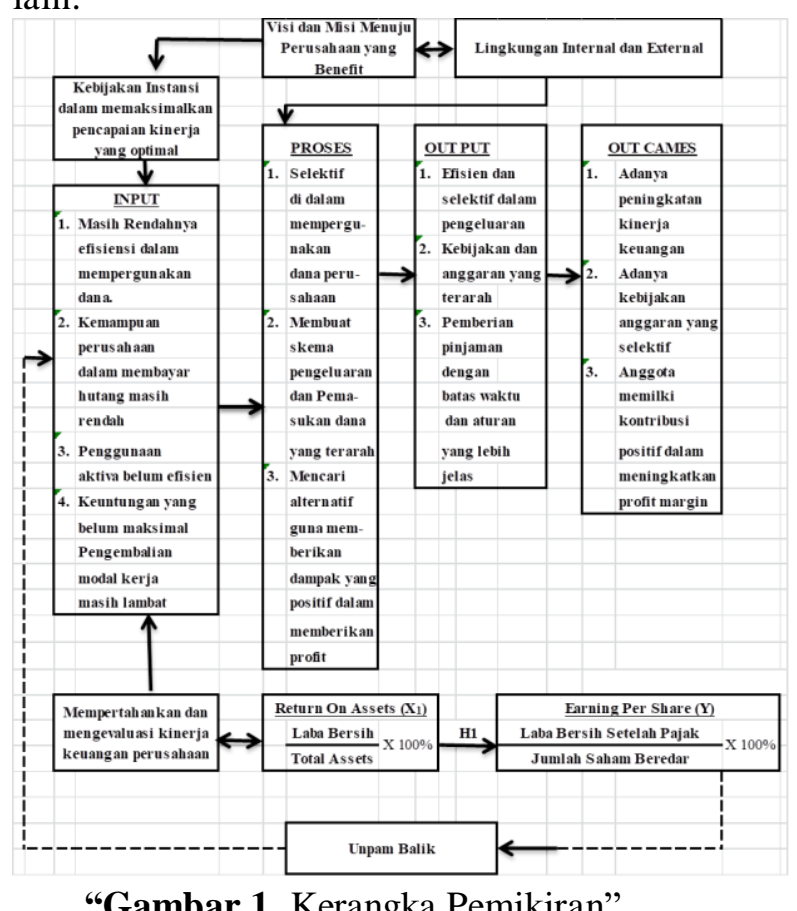

"Gambar 1. Kerangka Pemikiran".

\section{F. Hipotesis.}

Hipotesa yang dipergunakan adalah: $\mathrm{H} 0: \beta 1=0 \quad$ : "Tidak terdapat pengaruh

Return On Assets terhadap

Earning Per Share”. 
JRNAL ПMПAH

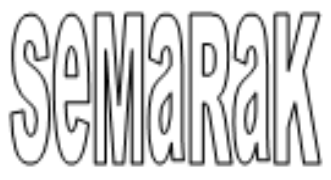

$\mathrm{H} 0: \beta 1 \neq 0 \quad$ : "Terdapat pengaruh

Return On Assets terhadap Earning Per

Share".

\section{METODE PENELITIAN}

Penelitian ini dilakukan dengan jumlah data sebanyak 10 tahun. Data sekunder pada "PT Multi Bintang Indonesia Tbk" melalui link IDX merupakan metode yang dipergunakan dalam penelitian ini. Selanjutnya penulis mempergunakan analisa data dalam penelitian ini dengan alat bantu Software "Statistical Product and Service Solutions" (SPSS) versi 24.

\section{HASIL SERTA PEMBAHASAN}

\section{A. Hasil}

1. Uji Asumsi Klasik (Uji Prasyarat).

Uji asumsi klasik dilakukan agar memperoleh hasil regresi yang bisa dipertanggung jawabkan, dan mempunyai hasil yang tidak biasa atau disebut Best Linier Unbiaxed Estimator (BLUE). Pengujian asumsi klasik yang terdiri dari:

\section{a. Uji Normalitas.}

Imam Ghozali 2016:154: "Menguji apakah dalam model regresi ni, ada variabel pengganggu atau memiliki residual distribusi normal" ini merupakan tujuan dari Uji Normalitas. Maka Uji Statistik akan tidak valid dengan jumlah sampel kecil. Dalam kesempatan ini terdapat dua cara guna mendeteksi apakakah residual berdistribusi normal atau berdistribusi tidak normal dengan mempergunakan sebuah analisis grafik serta uji statistik.

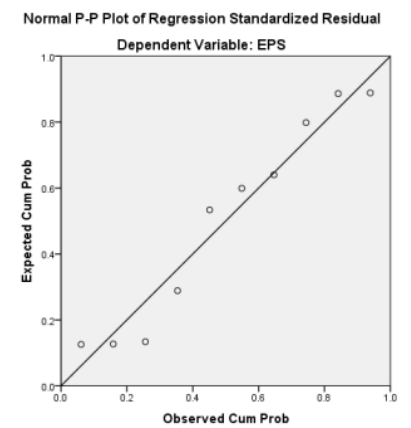

Berdasarkan gambar P-Plot di atas terdapat residual berdistribusi secara normal, yang dibuktikan dengan titik-titik residual yang terdapat pada tabel alurnya yang mengikuti garis diagonal dengan demikian bisa ditunjukan tingkat normalitas dengan nilai residualdan ada pada tabel tersebut yang artinya data tersebut berdistribusi normal.

\section{b. Uji Multikolinieritas.}

Yang dimaksud dengan multikolinieritas akan terjadi jika terdapat linier diantara variabel Independen terlibat dalam model tersebut. Selanjutnya mendeteksi terdapat VIF dalam kesempatan ini sama dengan 1/toleran. Sedangkan nilai cutoff nya umumnya yang dipakai yaitu dengan nilai toleran atau sama dengan VIF 10. Sehingga data tersebut tidak terdapat Multikolinieritas dengan nilai toleransi harus lebih kecil dari 0,10 atau VIF-nya kurang dari atau dibawah " 0,10 ".

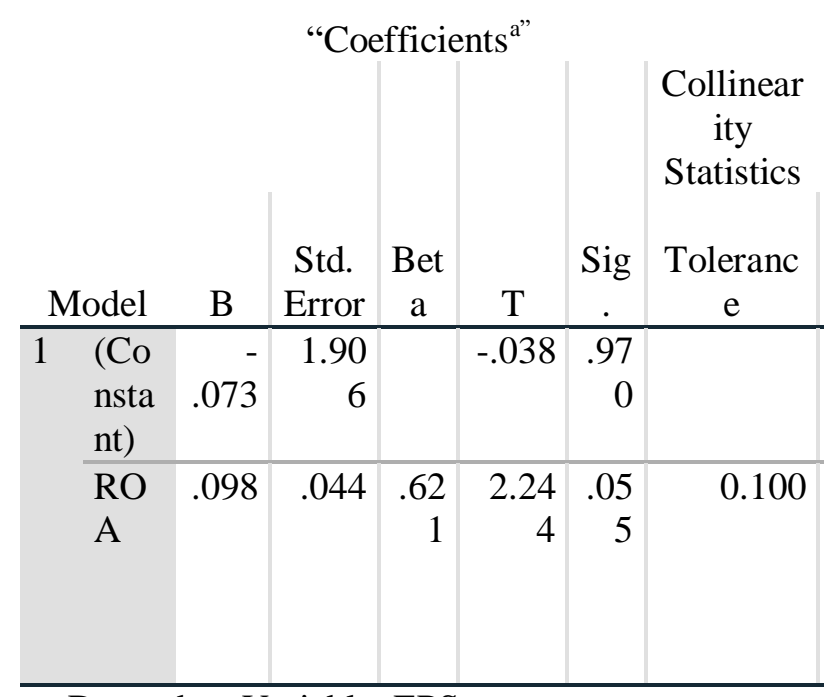

a. Dependent Variable: EPS

Berdasarkan data tersebut di atas di atas bisa dikatakan bahwa variable Independent mempunyai Faktor lebih kecil dari $10,00(1,000<10)$. selanjutnya bisa dikatakan jika tidak terjadi Multi terhadap data yang diujikan.

\section{c. Uji Autokorelasi.}

Berdasarkan pendapat Imam Gozali 2009:99 Berpendapat "Untuk mendapatkan 
JRNAL ПMПAH

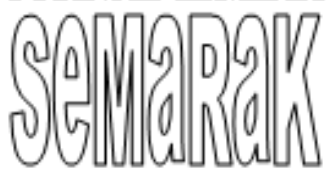

P-ISSN 2615-6849, E-ISSN 2622-3686

Jurnal Semarak,Vol.4,No.2,Juni 2021, Hal (90-97)

@Prodi Manajemen Fakultas Ekonomi Universitas Pamulang hasil jika ada hubungan antara yang mengganggu yang terdapat di " $t$ dengan $t-1$ " atau data tahun sebelumnya. Untuk mengistimasi model regresi linier dan merupakan model data Time Series maka memerlukan asumsi bebas autokorelasi, ini merupakan data yang dipergunakan.

\section{Hasil Uji Autokorelasi}

Model Summary ${ }^{\text {b }}$

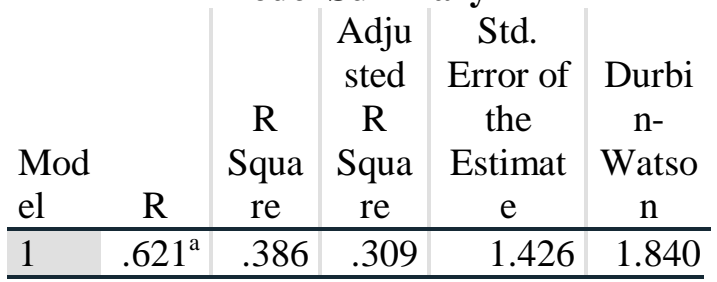

a. Predictors: (Constant), ROA

b. Dependent Variable: EPS

Dengan memperhatikan pengujian yang diperlihatkan pada model summary di atas akan didapatkan "Durbin-Watson" dengan nilai 1,840 dan nilai tersebut berada pada posisi antara interval 1,550-2,460. Selanjutnya data yang dipergunakan berada 1 pada posisi layak akan diolah sebagai data penelitian.

\section{d. uji heteroskedastisitas.}

Setelah dilakukan pengujian dalam a. Dependent Variable: EPS

Uji Heteroskedastisitas maka akan terdapat hasil olah data yang akan bisa disampaikan dalam hasil uji antaralain sebagai berikut:

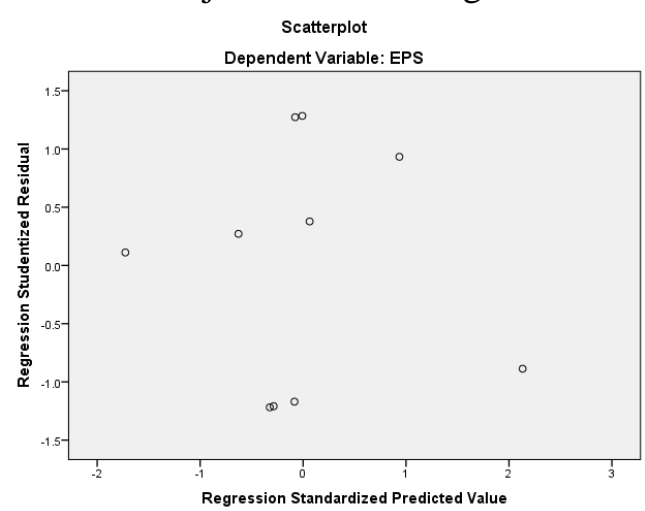

Trelihat dengan jelas hasil uji Heteroskedastisitas pada hasil olah menghasilkan bentuk sebaran dan tidak membentuk pola tertentu serta pola titik di atas terdapat penyebaran pada posisi diantara nilai "0" serta posisi "Y", selanjutnya membuktikan gambar di atas gangguan "Heterokedastisitas" belum didapatkan.

\section{Statistik Test}

a. Regression Analysis

Menurut (Ghozali, 2016)'Hubungan secara parsial antara satu variabel $X$ dengan Variabel Y" disebut dengan Analisis Regresi Linier Sederhana. Hal ini guna mengetahui arah hubungan antar varibel $\mathrm{X}$ dan $\mathrm{Y}$ terlihat data naik atau turun dan terlihat dari data bebas, jika hasil posisi independent terjadi positif atau negatif. Dalam kesempatan ini biasanya mempergunakan data berskala interval atau perbandingan.

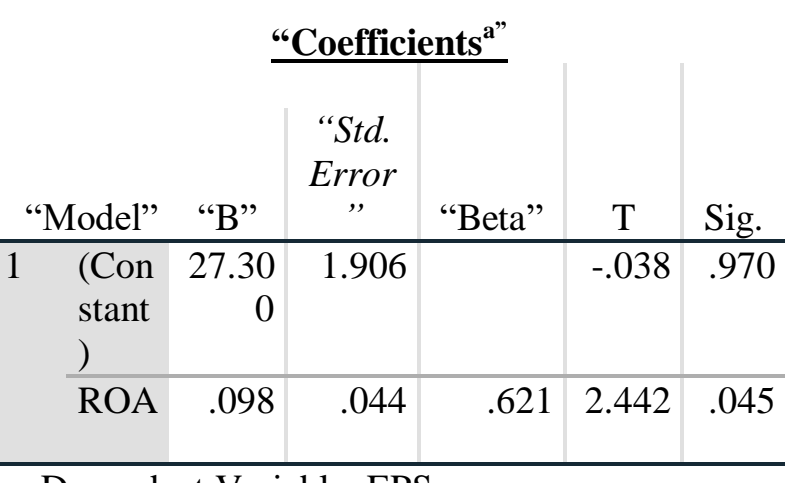

\section{"Coefficients ${ }^{\mathrm{a} "}$}

"Std.

Error

\begin{tabular}{|l|r|c|c|c|c|}
\hline $\begin{array}{l}\text { (Con } \\
\text { stant }\end{array}$ & $\begin{array}{r}\text { 27.30 } \\
0\end{array}$ & 1.906 & & -.038 & .970 \\
\hline ROA & .098 & .044 & .621 & 2.442 & .045 \\
\hline
\end{tabular}
didapat persamaan sebagai berikut: $\mathrm{Y}=27.300+0.098 \mathrm{X}$. Berdasarkan persamaan ini maka dapat diinterprestasikan secara parsial adalah hasil Constant (a) dengan nilai 27,300 ini berarti nilai variabel independent Retun On Assets (ROA) adalah 0 , maka nilai variabel ' $\mathrm{Y}$ " adalah "EPS" sebesar 27,300

\section{Uji Hipotesis}

Berdasarkan Gozali, 2016: "Seberapa jauh pengaruh antara satu variabel $X$ secara parsial terhadap variabel $Y$ " ini merupakan pengertian Uji Statistik t. Pengertian ini mempergunakan nilai guna menguji apakah variabel $\mathrm{X}$ berpengaruh terhadap Variabel Yatau tidak.

Berdasarkan data serta perhitungan maka dapat diinterprestasikan antara lain: 
JRNAL ПMПAH

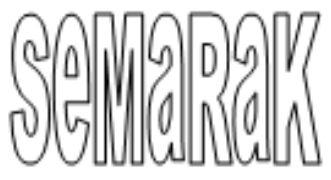

P-ISSN 2615-6849, E-ISSN 2622-3686

Jurnal Semarak,Vol.4,No.2,Juni 2021, Hal (90-97)

@Prodi Manajemen Fakultas Ekonomi Universitas Pamulang return on assets" "terhadap" "earning per share" terdapt nilai $t_{\text {hitung }}$ yaitu 2,442 serta nilai Sig yaitu 0,045 . Sedangkan $t$ tabel dengan tingkat signifikan $5 \%(0,05)$ dan rumus $t$ tabel $=\mathrm{t}(\mathrm{a} / 2 ; \mathrm{n}-\mathrm{k}-1)=\mathrm{t}(0,05 / 2 ; 10$ $2-1)=\mathrm{t}(0,025 ; 7)=2,36462$. Dengan demikian Ho ditolak dan Ha diterima, artinya Return On Assets (ROA) secara parsial berpengaruh terhadap Earning Per Share.

Berdasarkan (Ghozali, 2016) Koefisien Determinasi atau $\mathrm{R}^{2}$ dipergunakan guna mengukur berapa jauh kemampuan model akan menjelaskan variabel dependent. Dengan nilai koefisien deterninasi atau $\mathrm{R}^{2}$ yang dihasilkan dalam prosentase dengan nilainya pada posisi $0<\mathrm{R}^{2}<1$. Dengan " $R$ " hasilnya "kecil berarti kemampuannya variable independent untuk memperjelas variable dependent terbatas sekali. Pengujian dilaksanakan melalui dan melihat hasil " $R$ " Square. Adapun hasil olah data dalam penelitian ini antara lain:

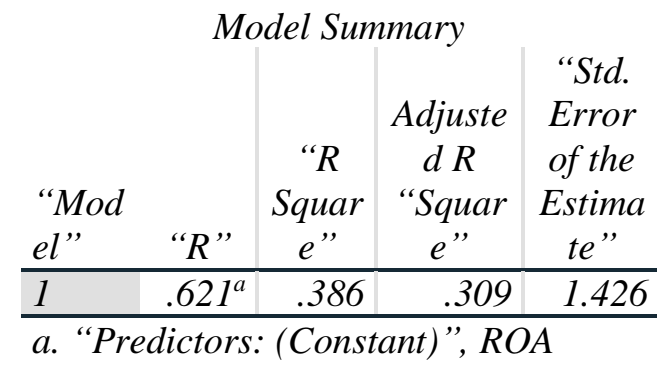

Sesuai hasil pengolahan data dalam penelitian ini hasil olah datanya bahwa " $R$ Square pada Uji Koefisien Determinasi" dengan nilai 0,386. Penelitian ini menggunakan $\mathrm{R}$ Square yang mempunyai nilai sebesar 0,386. Dengan demikian pengaruhnya "Variable $\mathrm{X}$ " mempengaruhi "Variable Y" yaitu $38,6 \%$ dan nilai $61,4 \%$ akan dipengaruhi oleh variabel yang lainnya.

\section{B. Pembahasan}

Dari hasil pengujian hipotesis "Variable ROA atau return on assets" pada " uji $t$ " ditunjukkan oleh nilai $\boldsymbol{t}_{\text {hitung }} 2,442$ dan nilai $\boldsymbol{t}_{\text {tabelel }} 2,36462$ sehingga $t_{\text {hitung }}$ akan lebih besar dari $t_{\text {tabel }}$ ari $(2,442>2,36462)$, adapun hasil probabilitasnya akan dibawah dari signifikasi atau $(0,0450<0,050)$. Serta
Uji koefisien korelasi "( $R O A)$ return on assets" hasil dari olah data nya adalah 0,621 pengujian diterima. Maka selanjutnya disimpulkan secara individu ROA akan mempengaruhi $E P S$.

\section{KESIMPULAN.}

Hasil dari olah data yang dilakukan bisa disimpulkan sebagai berikut:

Data Uji Parsial atau Uji T ada pengaruh nilai ROA (return on assets) terhadap Variable Y atau EPS (earning per share).

\section{DAFTAR PUSTAKA.}

BUKU :

Ghozali: 2016: Aplikasi Analisis Multivariete Dengan Program IBM SPSS. Semarang: Badan Penerbit Universitas Diponegoro.

Harahap, Sofyan Syafri: 2015. Analisis Kritis atas Laporan Keuangan. Edisi 1-10. Jakarta: Rajawali Pers.

Kasmir: 2016. "Analisis Laporan Keuangan". "Jakarta" : :Raja Grafindo Persada".

Sugiyono : 2016. "Metode Penelitian Pendekatan Kuantitatif, Kualitatif, serta R\&D. Bandung: Alfabeta.

Sujarweni, V. Wiratna. (2016). Metode Penelitian: Lengkap, Praktis, dan Mudah Dipahami. Yogyakarta: Pustaka Baru Press.

Supatmin (2020), Financial Management Konsep Dasar dan Penerapannya, Tangerang, CV AA Rizky.

JURNAL :

Iswara Abel. "Pengaruh Perputaran Kas" dan "Piutang", "Perputaran Persediaan" serta DER terhadap Return On Asset pada perusahaan Platic dan Kemasan yang terdaftar di Bursa Efek 
JRNAL ПMПAH

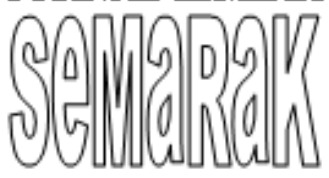

Indonesia periode 2010-2017. Sekolah Tinggi Ilmu Ekonomi Pelita Indonesia Pecan Baru Indonesia.Jurnal Ekonomi KIAT, Volume 30, Nomor 1, Juni 2019. ISSN: 1410-3834.

Susetyo Aris. "Pengaruh CR, DER, TOT "terhadap" Return On Asset yang tercatat di Jakarta Islamic Index periode 2015-2016. Sekolah Tinggi Ilmu Ekonomi Putra Bangsa. Jurnal Ilmiah Akuntansi dan Keuangan Volume 6, Nomor 1, Bulan Juni 2017. ISSN: 2548-9453.

Dede Solihin, :2019 "Pengaruh Current Ratio $(C R)$ dan Debt To Equity Ratio terhadap Return On Asset (ROA)" secara parsial dan secara simultan pada PT. Kalbe Farma Tbk, Jurnal Ilmiah Prodi Manajemen Universitas Pamulang, Vol.7, No.1, Juni 2019, Halaman : 115-122.

SUTIMAN, S. (2020). PENGARUH SET PELUANG INVESTASI, RASIO PEMBAYARAN DIVIDEN DAN BEBAN KEUANGAN TERHADAP PRICE BOOK VALUE PADA PERUSAHAAN MANUFAKTUR YANG TERDAFTAR DI BURSA EFEK INDONESIA PERIODE 2012-2016

Timan, S. (2017). ANALISIS SUMBER DAN PENGGUNAAN DANA DALAM UPAYA PENINGKATAN LIKUIDITAS DAN KEMAMPULABAAN PADA PT BANK X (PERSERO). Jurnal Mandiri: Ilmu Pengetahuan, Seni, dan Teknologi, 1(2), 289-310.

Timan, S. (2019). ANALISIS RASIO ROA DAN ROE DALAM MENILAI TINGKAT KESEHATAN PADA PT BANK MANDIRI (PERSERO) TBK TAHUN 2012-2017. Jurnal
Mandiri: Ilmu Pengetahuan, Seni, dan Teknologi, 3(1), 20-36.

Wartono, T., Tumanggor, M., Oktrima, B., \& Delimah, V. L. (2021, January). Analysis of Ratio and Financial Performance of Open Company Pharmaceutical Industry Which has Been Listing in Indonesia Stock Exchange (Case Study in Pharmaceutical Company PT. Kimia Farma. Tbk). In INCEESS 2020: Proceedings of the 1st International Conference on Economics Engineering and Social Science, InCEESS 2020, 17 18 July, Bekasi, Indonesia (p. 268). European Alliance for Innovation. 